Methods Using flowcytometric whole blood and platelet rich plasma double staining assay systems we analysed CD40 L expression. PE labelled CD40L (cloneTRAP1, Pharmingen) was employed, FITC-CD42b as detection system for platelets. 40 patients with diagnosis of SLE were included into this study, among them 10 with secondary APS and compared to 15 normal healthy donors (NHD). Results were analysed using Cellquest software (Becton Dickinson, San Jose, USA) differrenciating single from aggregated platelets under nonstimulatory and stimularory conditions (thrombin $30 \mathrm{uM}, \mathrm{ADP} 10 \mathrm{uM}$ ).

Results We found that CD 40 L expression was higher on aggregated compared to single platelets, where fluorescence means were close to baseline. We compared the whole blood method with platelet rich plasma and found lower background activity in whole blood test. Using established stimulators of platelets we could increase CD40L expression on platelets, espescially on aggregated platelets. Analysing CD40L expression in SLE patients we found no significant difference between SLE and NHD, neither on single or on aggregated platelets nor upon stimulation with ADP or thrombin. High CD40 L expression was observed in APS with highly significant differences compared to NHD and SLE analysing single platelets ( NHD < APS $(\mathrm{p}<0,0001)$ SLE $<$ APS $(\mathrm{p}<0,0001))$ as well as aggregated platelets. Upon stimulation with thrombin or ADP results were comparable indicating significantly higher CD40 L expression on platelets.

Conclusion We first describe high CD40 L expression on single and aggregated platelets in APS establishing CD40L as a novel platelet activation marker in APS. Interplay between CD40L on platelets and endothelial cells may contribute to procoagulatory conditions in APS. On the other hand we could not show altered CD40L expression in patients with SLE without clinical APS.

\section{OP0075 CHROMATIN CLEARANCE FROM NECROTIC CELLS BY A CONCERTED ACTION OF DNASE 1 AND SERINE PROTEASES RESEMBLES APOPTOTIC DNA- DEGRADATION}

M Napirei, H Karsunky, R Paddenberg, B Zevnik, S Wulf, T Möröy, HG Mannherz. RuhrUniversität Bochum, Abteilung Für Anatomie Und Embryologie, Bochum, Germany

10.1136/annrheumdis-2001.1239

Background Systemic lupus erythematosus (SLE) is an autoimmune disease characterised by the presence of antinuclear antibodies (ANA) which tend to accumulate as immunodeposits in different tissues and cause inflammations. One main feature of SLE-pathogenesis seems to be a reduced elimination of cellular debris after cell death. ${ }^{1,2}$ The recently generated mice deficient for the endonuclease Dnase 1 has underscored the important influence of defects of chromatin clearence for the onset of SLE. ${ }^{3}$

\section{Objectives}

Methods Cell nuclei of MCF-7 cells were isolated and either incubated with serum from Dnase 1 wildtype and Dnase 1 deficient mice or with recombinant human DNASE 1 alone and in combination with different serine proteases. Subsequently the DNA was isolated and analysed by agarose gel-electrophoresis.

DNA-degradation of MCF-7 cells incubated with different amounts of native or heat inactivated bovine serum in DMEM was analysed under apoptotic $(2 \mu \mathrm{M}$ staurosporin) and necrotic conditions $(1 \mathrm{mM} \mathrm{H} 2 \mathrm{O} 2)$ or after complement lysis due to the application of $6.7 \%(\mathrm{v} / \mathrm{v})$ rabbit complement. Subsequently the DNA was isolated and analysed.

Results Recombinant human Dnase 1 could induce an apoptoticlike DNA-fragmentation pattern in isolated MCF-7 cell nuclei by a concerted action with different serine proteases like plasmin, trypsin, a-chymotrypsin, thrombin and kallikrein. Dnase 1 alone only induces an unspecific, time-retarded DNA-degradation. Serum from Dnase 1 wildtype mice also induced DNA-laddering in cell nuclei whereas serum from knockout mice did not due to the lack of Dnase 1. The laddering capacity of wildtype serum could be inhibited by serine protease inhibitors. In contrast to apoptotic cells native bovine serum and not heat-inactivated serum induces internucleosomal DNA-laddering in MCF-7 cells lysed by rabbit complement or by the cytotoxic action of $\mathrm{H} 2 \mathrm{O} 2$. Conclusion This study gives insight into a new function of Dnase 1 which could be linked with its protective role towards the induction of an anti-DNA immunoreaction and subsequently towards SLE-pathogenesis.2,3 Dnase 1 in connexion with serine proteases is able to effectively degrade the genomic DNA of nuclei and of cells lysed by complement or the cytotoxic action of $\mathrm{H} 2 \mathrm{O} 2$. In contrast apoptotic cells were not influenced by serum Dnase 1 and serine proteases. Since apoptotic cells underly a cell-autonomous intracellular DNA-degradation process one can conclude that Dnase 1 in connexion with serine proteases fullfills this process for necrotic cells.

\section{REFERENCES}

1 Vanholder R, De Keyser F, Kips J, Praet M, Naeyaert JM. The pathophysiology of lupus erythematosus. Eur J Dermatol. 1998;1:4-7

2 Walport MJ. Lupus, DNase and defective disposal of cellular debris. Nat Genet. 2000;25:135-6

3 Napirei M, Karsunky H, Zevnik B, Stephan H, Mannherz HG, Möröy T. Features of systemic lupus erythematosus in Dnase 1-deficient mice. Nat Genet. 2000;25:177-81

\section{OP0076 KIDNEYS OF AUTOIMMUNE NZB/W MICE CONTAIN LONG-LIVED PC}

AH Radbruch, G Cassese, S Lindenau, B De Boer, S Arce, A Hauser, G Riemekasten, C Berek, F Hiepe, RA Manz. Cell Biology, Deutsches Rheuma-Forschungszentrum Berlin (DRFZ), Berlin, Germany

\subsection{6/annrheumdis-2001.1240}

Background NZB/W mice develop a disease similar to human systemic lupus erythematosus (SLE), including autoantibody production, hypergammaglobulinaemia and inflammation of the kidneys. Large numbers of lymphocytes infiltrate the kidneys of these mice but the role of this organ for the production of antibodies is not clear.

Objectives Here, we compare the role of bone marrow, spleen and inflamed kidneys of NZB/W mice for the activation of $\mathrm{B}$ cells and for the persistence of antibody secreting cells (ASC).

Methods NZB/W mice were immunised i.p.i with Ovalbumin and then boosted 1 month later. The number of antigen-specific PC present in spleen, bone marrow and kidneys was determined by Elispot. The frequency of different cell types was determined by flow-cytometry. The distribution of PC in the different organs was investigated by microscopy.

Results ASC are present in the kidneys of mice with full blown disease, as many as in the spleen and bone marrow, and 50 times more than in the kidneys of normal mice. In the kidneys, ASC are located mainly in the outer medulla, close to B- and $\mathrm{T}$ cell infiltrates. The specificity of the ASC in the inflamed kidneys is not restricted to self-antigens. After immunisation of $\mathrm{NZB} / \mathrm{W}$ 
mice with Ovalbumin (OVA), the antigen-specific ASC are found initially exclusively in the spleen. Weeks later, during a period of at least 3 month, OVA-specific ASC are found in stable and high numbers within the bone marrow and the kidneys of these mice, but no longer in the spleen. As determined by FACS, B cells with a germinal centre phenotype $(\mathrm{B} 220+/ \mathrm{PNA}+)$ are found only in very low numbers in the kidneys, but in high numbers in the spleen of NZB/W mice. Germinal centres could not be detected in the kidneys, but in the spleen. The lack of B cell activation and the kinetics of the appearance of OVA-specific ASC in the kidneys suggest that in autoimmune NZB/W mice, plasma cells generated during an immune reaction in secondary lymphoid organs, later accumulate and persist in the inflamed kidneys, like in bone marrow.

Conclusion These experiments identify the inflamed kidneys of $\mathrm{NZB} / \mathrm{W}$ mice as site of prime relevance for the homeostasis of plasma cells, irrespective of their specificity.

\section{Allied Health Professionals and Social League abstracts 2001}

\section{Rheumatoid arthritis}

\section{HP0001 THE EFFECTS OF RHEUMATOID ARTHRITIS ON SEXUAL EXPRESSION}

J Hill, R Thorpe, HA Bird. Clinical Pharmacology Unit (Rheumatism Research), University of Leeds, Leeds, UK

10.1136/annrheumdis-2001.1241

Objective To assess patients' perceptions of the effects of RA on their sexual relationships.

Method A self report questionnaire was distributed to patients attending rheumatology clinics in Leeds. It was returned by prepaid post to maintain anonymity.

Results Fifty-nine (80\%) questionnaires were returned: 2 by men, 2 were not completed. Womens ages ranged from 36-75 yrs (mean/median 58), men 38-76 yrs (mean 57: median 60). Median duration of RA for women was 18 yrs (mean 19: range 3-40); men 16 yrs (mean 17; range 5-35). Thirty-three women and 8 men were married (duration 1-47 yrs). Five women were single, 6 (1 man) widowed and 3 (1 man) divorced. Sixteen thought RA had strained their sexual relationship and $30 \mathrm{did}$ not. Eighteen thought their RA had altered their relationship but 23 did not. Twenty-three thought RA limited sexual intercourse. Problems cited included pain (11/23); positioning (6/23) and fatigue $(5 / 23)$. Sexual ability was of little importance to 20 patients but important/very important to 28 . Twenty discussed sexual problems with their partners, 19 did not. Sexual relationships were broached by the nurse practitioner in 19 cases but the remaining patients had not been offered discussion. Twenty said they would consider talking to a health professional if problems arose but 21 would not.

Conclusion Many patients with RA experience problems with their sexual relationships but few are given the opportunity to discuss the subject. The topic needs to be addressed and further work is necessary to assess the patients' requirements and the way in which sexual problems can be addressed within the context of patient management.
HP0002 FOREFOOT PLANTAR PRESSURES IN RHEUMATOID ARTHRITIS

${ }^{1} \mathrm{SJ}$ Otter, ${ }^{1} \mathrm{CJ}$ Baker, ${ }^{2} \mathrm{~A}$ Young. ${ }^{1}$ Podiatry, Leaf Hospital, Eastbourne, UK; ${ }^{2}$ Rheumatology, St Albans City Hospital, St Albans, UK

10.1136/annrheumdis-2001.1242

Background Elevated forefoot plantar pressures have been reported in patients with Rheumatoid Arthritis (RA). ${ }^{1}$ However, the temporal measures of plantar pressure have not been reported to date.

Objectives and methods A computerised foot pressure measurement system (Musgrave Footprint TM) was used to assess plantar pressure variables in 25 subjects with RA of between 5 and 10 years duration and an age/sex matched comparison group. The pressure variables studied were the magnitude and duration of peak plantar pressure.

Results There were no significant differences in the magnitude of peak pressure between the groups. Whereas the duration of peak pressure was significantly longer in the rheumatoid group $(\mathrm{p}>0.001)$.

Conclusion Subjects with RA in this study demonstrated marked increases in the temporal parameters of plantar pressure distribution rather than those of amplitude.

Recommendations The implications for management - using footwear or orthoses; are that temporal, rather than spatial parameters, should be addressed.

\section{REFERENCE}

1 Woodburn J, Helliwell P. Relationship between heel position and distribution of forefoot plantar pressures and skin callosities in RA. Ann Rheum Dis. 1996;55:806-10

\section{HP0003 INTENSIVE THERAPY OF SYSTEM VARIANT JUVENILE RHEUMATOID ARTRITIS}

TM Fomenko, GI Donov, IE Schahbazyan. Pediatric, Sechenov Medical Academy, Moscow, Russia

10.1136/annrheumdis-2001.1243

Combined plasmapheresis (PP) with methotrexate was used in 39 children aged 2-15 with severe system variant juvenile rheumatoid artritis. Juvenile rheumatoid artritis accomponied persistence infection and septic complication.

PP was conducted every other day 5 times. After each PP followed by immunosupressants therapy (PIT) (bolus methylprednisolone, methotrexate). Total dose was at most $15 \mathrm{mg} / \mathrm{week}$.

Then patients received injections immunoglobulines every other day 3 times. Total dose immunoglobulines was 0,4-0,6 $\mathrm{mg} / \mathrm{kg}$. 12 patients had herpes infection. Before intensive therapy patients received zovirax.

During first week by used intensive methods of therapy used to disappear basic indication of disease. After 2 weeks state of patients was stably and not required intensive therapy.

9 patients from 39 had remission about 12 months. These patients used intensive methods of therapy repeatedly.

12 patients had exacerbation a year later after intensive therapy. These patients received only basic therapy.

1 died 2 years after the end of the treatment.

17 patients developed complete remission in 16-36 months. All these patients received basic therapy (prednisolone, methotrexate). 